Robertson's article, comparing the strong commercial tradition of Ga women in the Ghanaian capital of Accra with the more crisis-driven trade activity among the Kikuya of Kenya, is particularly sophisticated. She argues that the "comparative advantage" of the former lies in the fact that, for a variety of reasons, multiple generations of $\mathrm{Ga}$ women live and work together in Accra, and consider trade a right and custom as well as a necessity. Neither indigenous household structure nor colonial native policies in Kenya historically facilitated the development of intragenerational women's commercial enterprises, but Robertson finds evidence that contemporary poverty and marital instability are forcing women to change how and where they live and work. The result is that although they are poorer they are also, like their Ghanaian counterparts, more economically autonomous of men, and more committed to that autonomy. This is precisely the kind of analysis that sheds light on the dynamic between gender and economic change. VerEcke's chapter details a more microlevel study of Islamic Northern Nigeria and Downing's macrolevel analysis of Southern Africa, both with interesting new findings.

Unfortunately, some of the articles are quite weak, and seem more interested in portraying their subjects in a positive if not heroic light than in contributing anything to existing knowledge. Whereas the introduction claims that all the chapters are based on original research, a few of them make scant reference to the authors' own findings, and instead rely heavily on oftentimes inappropriate quotes from outdated secondary sources. Others contain more evidence of fieldwork, but no new observations; they simply remark (as did the earliest studies in the 1970s) that the market women work hard to feed their families, and contribute to economic development. All very true, but after several reiterations not very useful.

The sense of redundancy is compounded by the fact that many of the articles begin by reviewing the same standard "women in development" literature; the editors could have more effectively put this material in the introduction. In addition, their range of case studies should have extended beyond anglophone Africa. In francophone West and Central Africa especially, women traders have long participated prominently in multiple forms of commerce as well as national and local politics, but against a backdrop of laws, policies and commercial structures formed under quite different colonial administrations. They deserve at least some mention in a book that claims to cover the whole of subSaharan Africa.

\title{
Green Globe Yearbook of International Co- operation on Environment and Development 1997, edited by Helge Ole Bergesen and Georg Parmann. New York: Oxford University Press, 1997. pp. 358, index.
}

\section{Reviewed by David Frossard, Assistant Professor of Liberal Arts and International Studies, Colorado School of Mines.}

As someone who teaches undergraduate engineering students about the environmental and social effects of a technological world view, I sometimes find myself 
less than optimistic about the future of the planetary ecosystem. Part of my mood can no doubt be attributed to the "usual suspects " worrisome population increases; faltering fisheries, forests, and farmlands; accelerated extinctions of species, and on and on. But equally sobering to me is the sense that most of my students--budding engineers and professional scientists who will help shape the technologies of the future--see little need for alarm. Whereas some (if not all) of these very intelligent young people will concede that the planet is today facing unprecedented ecological challenges, few are willing to grant the possibility that these problems are beyond the scope of technology alone to remedy. Whatever previous generations of humans have "broken," students tell me, a new generation of scientists can "fix," with more and better technology.

Of course, I wish them luck. Technology will no doubt play an important role in future approaches to environmental sustainability, particularly in developing cleaner substitutes for fossil fuels and new "preventative" techniques in industrial engineering. But I am also apprehensive. I hope that their technological optimism reflects a justified confidence in their own abilities, rather than simple hubris. I worry that, in their search for technological answers to ecological problems, these students exclude other important possibilities from their calculations. I'm afraid that when economics, politics, and culture go by the wayside, the environment is inevitably reduced to a set of sterile calculus equations, rather than the much messier, imponderable "social equations" that reflect a richer reality.

In that sense, the Green Globe Yearbook offers a necessary antidote to simplistic, technological-determinist views of the global ecology--whether those views are held by undergraduates or by influential policy "wonks" inside the Washington beltway. The yearbook, published annually since 1992 by Norway's Fridtjof Nansen Institute, an international resource management think tank, is eloquent testimony to the breathtaking complexity of international political and social (rather than purely technological) efforts to deal with environmental decline.

The volume is divided into a 60-page "evaluations" section (more on this later), and a much longer "reference" section. The latter is an invaluable resource, deftly summarizing scores of international agreements on environment and development. Each summary is accompanied by a map showing signatories to that agreement, and a final table indicates which of almost 200 nations have ratified the various conventions.

Included in this volume are updated summaries of international conventions on atmospheric pollutants and ozone depletion; marine pollution (particularly by oil); marine and freshwater resources; nature conservation and terrestrial living resources; and nuclear safety. The objectives of a particular agreement, its scope, time and place of adoption, funding sources, governing body, and other administrative details are noted, along with the far more important nuts-and-bolts details of the convention: What rules does the agreement put into place? How is compliance monitored? How is it enforced, if at all?

The summaries will rapidly bring nonspecialists (most usefully, educators, activists, and policymakers) up to speed on particular environmental and development agreements. For example, one might quickly discover (on pages 154-56) that the International Convention for the Regulation of Whaling is supervised by the International Whaling Commission (IWC), based in London; that the 1997 budget totals approximately 1.15 million British pounds; that the agreement provides for a complete moratorium on harvesting certain whale species, designates whale sanctuaries, sets maximum catches, and so on. This entry also gives a concise history of measures taken by the commission over the years. 
The language and content of the yearbook are straightforward and concise, though sometimes to a fault. For instance, controversial IWC decisions to allow aboriginal whaling for subsistence purposes, or Japan's supposed "scientific" whaling, are treated in a single sentence. The yearbook is a first step at understanding these international agreements, the actors who participate in them, and the politics that surround them, but only a first step. In addition, I'd like to see the entire text of each agreement made available for closer analysis, perhaps as part of a companion CD. To the editors' credit, they have provided World Wide Web addresses, where they exist, for official information online. (In that spirit, I direct you to the Fridtjof Nansen Institute's home page at http:// www.tjener.uninett.no/ fni/ and to http://www.tjener.uninett.no/ fni/ggy.htm for the Institute's own description of the yearbook.) But in the interest of broad political dialog, why not also provide a judiciously selected list of online commentaries from organizations critical of particular conventions?

In addition to important international conventions, the yearbook's reference section profiles a score of intergovernmental organizations dealing with various facets of development and environment--from the Commission on Sustainable Development to the International Monetary Fund, World Bank, and World Trade Organization. I would be less than sanguine about this selection of mainstream players if not for a companion section on non-governmental organizations and "other networking instruments" that profiles three dozen activist environmental organizations, from Greenpeace International to the Pesticide Action Network, the Sierra Club, and the Third World Network.

Again, the reader should take the given information as a starting point. For instance, although the World Bank may indeed see its role in the world as raising "standards of living in developing countries by channeling financial resources to them from industrial countries," that is hardly the reality experienced by people in dozens of impoverished countries now undergoing Bank-prescribed "structural adjustment" a topic conspicuous by its absence. Similarly, the straightforward reporting of Greenpeace's goal "to end the threat of nuclear weapons, nuclear weapons testing, nuclear power, and nuclear waste" doesn't quite capture the drama of the organization's attempts to enter nuclear-weaponstesting zones in the South Pacific, or the sinking of the Greenpeace ship Rainbow Warrior in New Zealand by French secret agents.

At the very least, however, the yearbook is an appropriate first resource with which to identify important international agreements and major players in global political struggles over development and environment.

From a pedagogical viewpoint, this is a book from which students could benefit (although few will see it outside a library unless it is someday published in a cheaper, paperback form). After reading about a few dozen international agreements to control everything from ozone depletion to aircraft-engine emissions, it is likely to be much more difficult for anyone to dismiss these issues as the sky-is-falling ravings of environmental extremists, as some students are wont to do.

But I can hear my students now: "Well, sure, the yearbook shows that a bunch of countries say these environmental issues are important. But isn't that just windowdressing? Do these conventions really do any good in practice? Isn't it all just public relations?" These are fair questions, ones that we all should ask ourselves. They are also questions the yearbook editors obviously find important. In the volume's "evaluation" section mentioned earlier, reviewers take aim at particular conventions and political actors and evaluate their efficacy. 
In a heavily referenced keynote article, Peter H. Sand, former Secretary-General of the Convention on International Trade in Endangered Species of Wild Fauna and Flora (CITES), draws some disquieting conclusions about the future of the CITES agreement in regulating transnational trade in endangered species. "There are signs that CITES may indeed have reached its outer limits," he writes (p. 26). "Considering the treaty's focus on transnational trade, the advent of large free trade areas--aimed at the abolition of internal trade boundaries--is bound to diminish the future relevance of CITES-type border controls, unless new methods of regulation can be developed to cope with geopolitical changes of that order."

In an evaluation of the United Nations Development Programme (UNDP)--an "organization still in search of a role"--Poul Engberg-Pedersen and Claus Hvashfj Jfrgensen argue persuasively that the UNDP can be of best use building institutional skills at a local level. "Developing-country governments are quite willing to sign and ratify international environmental agreements, but are lacking in capacity for implementation at national level," they argue (p. 37). "Given the UNDP's centralized structure, its institutional presence in 130 countries, its close links with recipient governments, its multisectoral mandate, and its instruments of technical co-operation, we argue for a much stronger UNDP focus on capacity development assistance to the governments of developing countries."

In other insightful articles Lisa Jorgenson details the substantial challenges to environmental regulation of international waters; Leif E. Christoffersen profiles the International Union for Conservation of Nature and Natural Resources (now known simply as the World Conservation Union); Jacob Park warns about challenges facing the World Wildlife Fund for Nature.

If anything, I would like to see far more of these evaluations in future editions of the yearbook. Ideally, each treaty and organization listed would have a companion overview (though, admittedly, this would require a much greater commitment of resources from authors, funding sources, and Oxford University Press). In the meantime, however, previous yearbooks remain available (search the keywords "Green Globe Yearbook" at http://www.amazon.com for details) and contain evaluation articles on a wide variety of important topics. An index of those topics is available in the current volume.

In sum, the Green Globe Yearbook is a valuable resource and an important contribution to the global political dialog on environment and development--one that activists, policy makers, teachers and, yes, their students should have handy.

\section{After the USSR. Ethnicity, Nationalism, and Politics in the Commonwealth of Independent States, by Anatoly M. Khazanov. Madison: University of Wisconsin Press. 1995, 310 pages.}

\section{Reviewed by Pal Kolstö, Department of East European and Oriental Studies, University of Oslo}

Anatoly Khazanov worked as a senior researcher at the Soviet Institute of Ethnography and Anthropology in Moscow before he left for the West as a refusenik in 